\title{
The role of eosinophils in necrosis mainly in single-system Langerhans cell histiocytosis
}

Yoshinori Kawabata ${ }^{1 *}$, Nobukazu Tomichi ${ }^{2}$, Mishie Ann Tanino ${ }^{3}$, Takashi Ogura ${ }^{4}$, Masashi Kawamoto ${ }^{5}$, Yasutsugu Fukushima ${ }^{6}$, Kazuyoshi Kurashima ${ }^{7}$ and Yoshihiko Shimizu ${ }^{8}$

*Correspondence: kawabata.yoshinori@pref.saitama.lg.jp

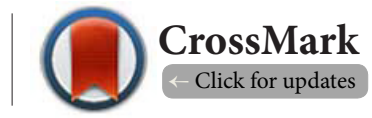

'Division of Diagnostic Pathology, Saitama Cardiovascular and Respiratory Center, Japan.

${ }^{2}$ LSI Medience Corporation Pathology and Cytology Center, Japan.

${ }^{3}$ Department of Surgical Pathology, Asahikawa Medical University Hospital, Japan.

${ }^{4}$ Department of Respiratory Medicine, Kanagawa Prefectural Cardiovascular and Respiratory Center, Japan.

${ }^{5}$ Department of Diagnostic Pathology, Teikyo University Hospital, Mizonokuchi, Japan.

${ }^{6}$ Department of Respiratory Medicine and Clinical Immunology, Dokkyo Medical University Saitama Medical Center, Japan.

${ }^{7}$ Department of Respiratory Medicine, Saitama Prefectural Cardiovascular and Respiratory Center, Japan.

${ }^{8}$ Division of Diagnostic Pathology, Saitama Cardiovascular and Respiratory Center, Japan.

\begin{abstract}
Background: Single-system Langerhans cell histiocytosis (LCH) shows massive infiltration of eosinophils and occasional necrosis and cyst/cavity formation, but the cause of the necrosis remains unclear. The role of eosinophils in necrosis in single-system LCH has not been examined yet, and therefore,we investigated their role pathologically.

Methods: Biopsy/lobectomy specimens were collected in 49 cases (50 lesions, 30 males, 19 females; mean age 31 years) satisfying the pathological criteria of LCH from 22 institutions from the beginning of 1998 to the end of 2011. Sources of organs were 33 lungs and 17 other organs. Forty-seven cases showed single-system LCH and 2 cases showed multiple-system LCH without involvement of "Risk Organs". The interrelationship between eosinophils and necrosis, various kinds of tissue destruction, and subsequent findings were investigated. Cellular features of the earliest LCH lesion were also examined in detail. Ordinal histopathological and immunohistochemical examinations that included anti-eosinophilic antibodies were used.
\end{abstract}

Results: Destructive features and subsequent findings of pulmonary LCH from 30 cases were as follows: vascular destruction, 6; cyst/cavity formations, 22; filling of tissue defect, 15; and elastic tissue, 30,and reticuline fiber destruction, 17. Tiny necroses accompanying degranulation of dead eosinophils without fibrosis werepresent in 2 cases. Large numbers of Langerhans cells and eosinophils were observed in the cellular-stage lesions and were associated with each other. Destructive features and subsequent findings of non-pulmonary LCH from 17 cases were as follows: coagulative necrosis of various extent without fibrosis, 8; cavity formation and cell shedding, 5; and reticuline fiber network destruction, 15. Large numbers of dead eosinophils accompanying degranulation were noted in most of the necrotic lesions along with a few Charcot-Leyden crystals. Degranulation of neutrophils in the necrotic lesions was limited to live cells.

Conclusions: These findings suggest an intimate relationship between preceding degranulation of eosinophils in necrosis and various kinds of tissue destruction following necrosis in LCH.

Keywords: Degranulation of eosinophils, degranulation of neutrophils, Langerhans cells, pathological examination 
Kawabata et al., Journal of Histology \& Histopathology 2021,

http://www.hoajonline.com/journals/pdf/2055-091X-8-1.pdf

\section{Introduction}

Langerhans cell histiocytosis ( $\mathrm{LCH}$ ) integrates eosinophilic granuloma, Hand-Schüller-Christian disease, and LettererSiwe disease due to the proliferation of histiocyte-like cells, which have now been proved to be Langerhans cells $[\mathbf{1}, \mathbf{2}]$. The BRAF V600E mutation is an important genetic factor in $\mathrm{LCH}$ [3], and new terminology (inflammatory myeloid neoplasia) was introduced $[4,5]$.

Nodular-shaped, single-system LCH is mainly composed of Langerhans cells and eosinophils histologically, and hence it was first named eosinophilic granuloma [6]. Serial computed tomography scans have suggested that radiological pulmonary $\mathrm{LCH}$ progresses over time from nodules to cavitated nodules and then to thick-walled cysts $[7,8]$. Intralesional cytokines released from Langerhans cells and T cells are thought to play a role including in necrosis, especially in bone and other organs [9-11], but the cause of this necrosis, which is followed by a destructive process, remains unclear, and until now, the role of eosinophils has also remained unclear. We have attempted to disclose the interrelationship of necrosis in LCH with eosinophilic degranulation from the pathologic aspect and have achieved this aim.

\section{Materials and methods \\ Patients and tissue collection}

Biopsy/lobectomy specimens in 49 cases of $\mathrm{LCH}$ (50 lesions) were collected from 22 institutions in Japan from the beginning of 1998 to the end of 2011 . The patients comprised 30 males and 19 females whose ages ranged from 1 month to 62 years (mean age, 31 years). No patient was treated before a diagnosis was made. Sources of organs were lungs, 33; bones, 14; lymph nodes, 2; and soft tissue, 1. Histopathological methods used for diagnosis were surgical lung biopsy (31 cases), transbronchial lung biopsy (1 case), lobectomy for lung cancer (1 case), and excisional biopsy or curettage at the time of procedure for other organs (17 cases). Histologically, all materials were diagnosed as $\mathrm{LCH}$ because of the aggregation of characteristic Langerhans cells having a convoluted nucleus with a groove, and this was confirmed by immunostaining using antibody for $\mathrm{CD} 1 \mathrm{a}$ [5] (Figures 1A-1C) in the lesion by YK and NT. Forty-seven patients presented with single-system one organ $\mathrm{LCH}$, and 2 patients presented with multiple-system LCH without involvement of "Risk Organs" ( 2 organs and 5 organs, respectively). Among the 33 patients with pulmonary $\mathrm{LCH}, 28$ were smokers, 2 were non-smokers, and smoking

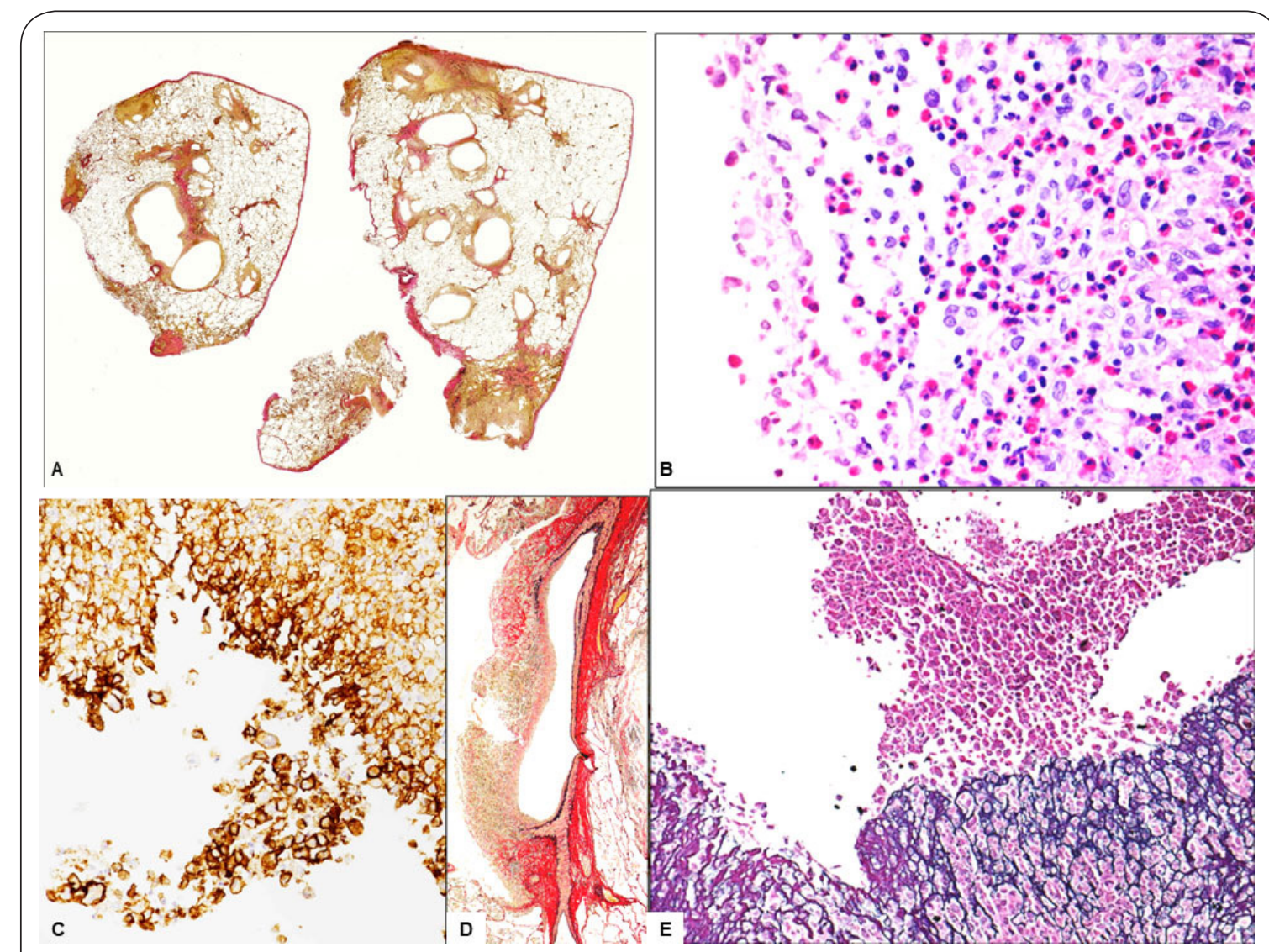

Figure 1. Histology of pulmonary Langerhans cell histiocytosis.

A. Panoramic view of many cysts/cavities (Elastica van Gieson, EvG). B. Characteristic features of LCH at the edge of a cavity (hematoxylin \& eosin, H\&E, $\times 400$ ). C. Langerhans cells (anti-CD1a antibody, $\times 200)$. D. Artery $(\mathrm{EvG}, \times 40)$. E. Shedding of Langerhans cells (reticular fiber staining, $\times 100)$. 
status in 3 was unknown.

This study was an interdisciplinary, multi-institutional, retrospective study approved by the Ethics Committee of Saitama Prefectural Cardiovascular and Respiratory Center (no. 2015013; Dec. 28, 2015) and each participating institution.

\section{Lung}

A representative single slide containing the earliest-stage lesion was stained with hematoxylin and eosin (H\&E), elastica van Gieson (EvG), and reticular fiber staining. Immunostaining was performed using EG2 (mouse monoclonal antibody to eosinophilic cationic protein; Nichirei Biosciences, Inc., Tokyo, Japan), anti-hNE antibody (mouse monoclonal antibody to neutrophilic elastase; Kyowa Pharma Chemical Co., Ltd., Toyama, Japan), and anti-CD4 antibody, anti-CD8 antibody, and anti-CD1a antibody (all mouse monoclonal antibodies from Nichirei Biosciences, Inc.).

Check points were the number of lesions, the presence of vascular destruction, the presence and numbers of cysts or cavities (tissue defects related to discharge of necrotic material), the presence of degenerated cell shedding into the cavity, filling of tissue defects by granulation tissue such as a filled cavity [12] or organized hematoma after lung laceration [13], the presence of disruption of elastic fibers and reticuline fibers, and the presence of necrosis per 1 slide. The extent of infiltration of eosinophils and neutrophils and their degranulation in necrosis were also checked. Cysts and cavities were evaluated as different categories. However, intermediate histological findings were noted between cysts and cavities, and the term cyst/cavity is used when differentiation was difficult.

Next, the numbers of inflammatory cells in one earliest-stage, non-necrotic lesion per high-power field (HPF, $\times 400)$ were counted with the help of immunostaining. The presence of $\geq 100$ cells/HPF was semi-quantitatively expressed as density $3,20-100$ cells as density 2 , and $<20$ cells as density 1 . The degree of cell shedding into the cavity was defined as follows: $\geq 100$ cells as density 2 and $<100$ cells as 1 . The presence and numbers of granulocytic degranulation including necrotic areas were also checked, and the presence of $\geq 20$ cells/HPF was classified as density 2 and $<20$ was classified as density 1 .

\section{Bone, lymph node, and soft tissue}

One slide was checked in 15 patients, and 3 slides were checked in 2 patients. Staining methods were the same as with the lung tissue. Check points were the presence of necrosis (including that of fibrosis and lytic or destructive change of the reticuline fiber network in necrosis), cavities, shedding of inflammatory cells into the cavity, and disruption of reticuline fibers in lesions per the entire slide. The degree of necrosis was defined as follows: $>1 \mathrm{~cm}^{2}$ was classified as grade 3 , intermediate as 2 , and $<4 \mathrm{~mm}^{2}$ as 1 per 1 slide. Numbers of inflammatory cells were counted in one representative earliest-stage lesion. The characteristics of the necrosis, necrotic cell structure, nuclear staining, and Charcot-Leyden crystals per the entire areas of necrosis were also checked. The numbers of eosinophils and neutrophils and their degranulation were counted in the representative necrotic area.

\section{Statistical analysis}

Demographic data are expressed as the mean \pm standard deviation (SD). The association between Langerhans cell density and that of other inflammatory cells was analyzed by Spearman's rank test. The Mann-Whitney U test was used to analyze comparisons in density between Langerhans cells and eosinophils and also between eosinophils and neutrophils, and the comparison of the density of eosinophils, neutrophils, and their degranulation between non-necrotic lesion and necrotic areas in non-pulmonary LCH. A $P$ value of $<0.05$ was considered statistically significant.

\section{Results \\ Lung}

Pathological characteristics of the 33 patients (22 men and 11 women, mean age 37 years) with pulmonary LCH are summarized in Tables 1 and 2. The mean number of lesions per 1 slide was 7.8. The lesions were observed at various stages (cellular, cellular and fibrous, and fibrous).

The general feature of the lesions was that of a tissuedestructive process and subsequent findings that were present in 6 cases of unilateral, muscular pulmonary arterial destruction (on the same side of the respiratory bronchiole, Figure 1D) at the edge of the cavity wall, 22 cases with a mean of 3.1 cyst/cavity formations (Figure 1A-1E), 20 cases of shedding of inflammatory cells into a cellular-stage cavity except for one cellular and fibrous-stage cyst/cavity (Figure 1C and 1E), 15 cases of filling of a tissue defect by granulation tissue

Table 1. Patient sex and age and pathological features of one representative slide from the 33 pulmonary $\mathrm{LCH}$ cases.

\begin{tabular}{lcc}
\hline & Number (\%) & Mean \pm SD \\
\hline Sex (male/female) & $22 / 11$ & -- \\
Age (years) & -- & $37 \pm 15$ \\
Number of lesions & -- & $7.8 \pm 7.0$ \\
Vascular destruction & $6(18)$ & -- \\
Cyst/cavity formation & $22(67)$ & $3.1 \pm 3.7$ \\
Shedding of inflammatory & $20(61)$ & $1.7 \pm 0.5$ \\
cells into cyst/cavity & & \\
Filling of tissue defect & $15(45)$ & $0.8 \pm 1.0$ \\
$\begin{array}{l}\text { Destruction of elastic fibers } \\
\text { Destruction of reticuline }\end{array}$ & $30(91)$ & -- \\
fibers & $17(52)$ & -- \\
Necrosis of lesion & & \\
& $2(6)$ & E 2.5, D/E \\
& & $2, \mathrm{~N} \mathrm{1.5,}$ \\
\hline
\end{tabular}

D/E: Degranulation of eosinophils; D/N: Degranulation of neutrophils, E: Eosinophils, LCH: Langerhans cell histiocytosis; N: Neutrophils; SD: Standard deviation 
(Figure 2A), and in 30 and 17 cases of structural framework destruction (elastic tissue and reticuline fibers, respectively, Figure $\mathbf{2 B}$ and $\mathbf{2 C}$ ). Tiny necroses of up to $1 \mathrm{~mm}$ in size (Figure 2D) with reticuline framework destruction were noted in 2 cases, and the density of eosinophils and their degranulation in these necroses were 2.5 and 2 including live, degenerative, and dead eosinophils (cells with an unstained or ghost-like nucleus) (Figure 2D, upper and lower insets), and those of neutrophils (only live cells) were 1.5 and 1 , respectively.

The density of the inflammatory cells is noted in Table 2. The proliferation of Langerhans cells and infiltration by various inflammatory cells were variously distributed (focal to diffuse) in even one lesion. In the earliest stage of the lesion, the density of Langerhans cells was 2.6, eosinophils (Figures $1 \mathrm{~B}$ and $2 \mathrm{E}$ ) was 2.1, and neutrophils was 0.7. The difference in density was not statistically significant between Langerhans cells and eosinophils, but it was statistically significant between eosinophils and neutrophils. An association with the density of Langerhans cells was noted between that of eosinophils, degranulation of eosinophils (Figure 2E inset, black arrow) with uptake by macrophages (Figure 2E inset, red arrow), and degranulation of neutrophils.

\section{Bone, lymph node, and soft tissue}

Pathological characteristics of the 17 non-pulmonary LCH cases (10 males and 7 females, mean age 20 years) are summarized in Tables 3 and 4. The lesions were at various stages, and the general feature of the lesions was that of a tissue-destructive process and necrosis. Histological findings were as follows: necrosis of various extents at the cellular stage except for one lesion in 8 cases (microscopic to extensive, Figure $3 \mathrm{~A}$ ), no fibrosis but destruction of the reticuline network in necrosis (3B), cavity formation and cell shedding in 5 cases (mean 1.8 among 5 cavities, Figure $3 \mathrm{C}$ ), and reticuline fiber network destruction of various degrees, including in every necrotic area, in 15 cases (Figure 3B and $\mathbf{3 C}$ ).

The distribution of eosinophils and neutrophils in the lesions varied from area to area. In the earliest cellular-stage lesion, LCH was mainly composed of Langerhans cells (density 3 in all) and eosinophils, with no significant difference, but the difference between the density of eosinophils and neutrophils was statistically significant.

Characteristics of the necrosis are noted in Table 4. Mean size was grade 2.3 , and 4 cases showed multiple necroses. All cases showed coagulation necrosis without lytic necrosis. The

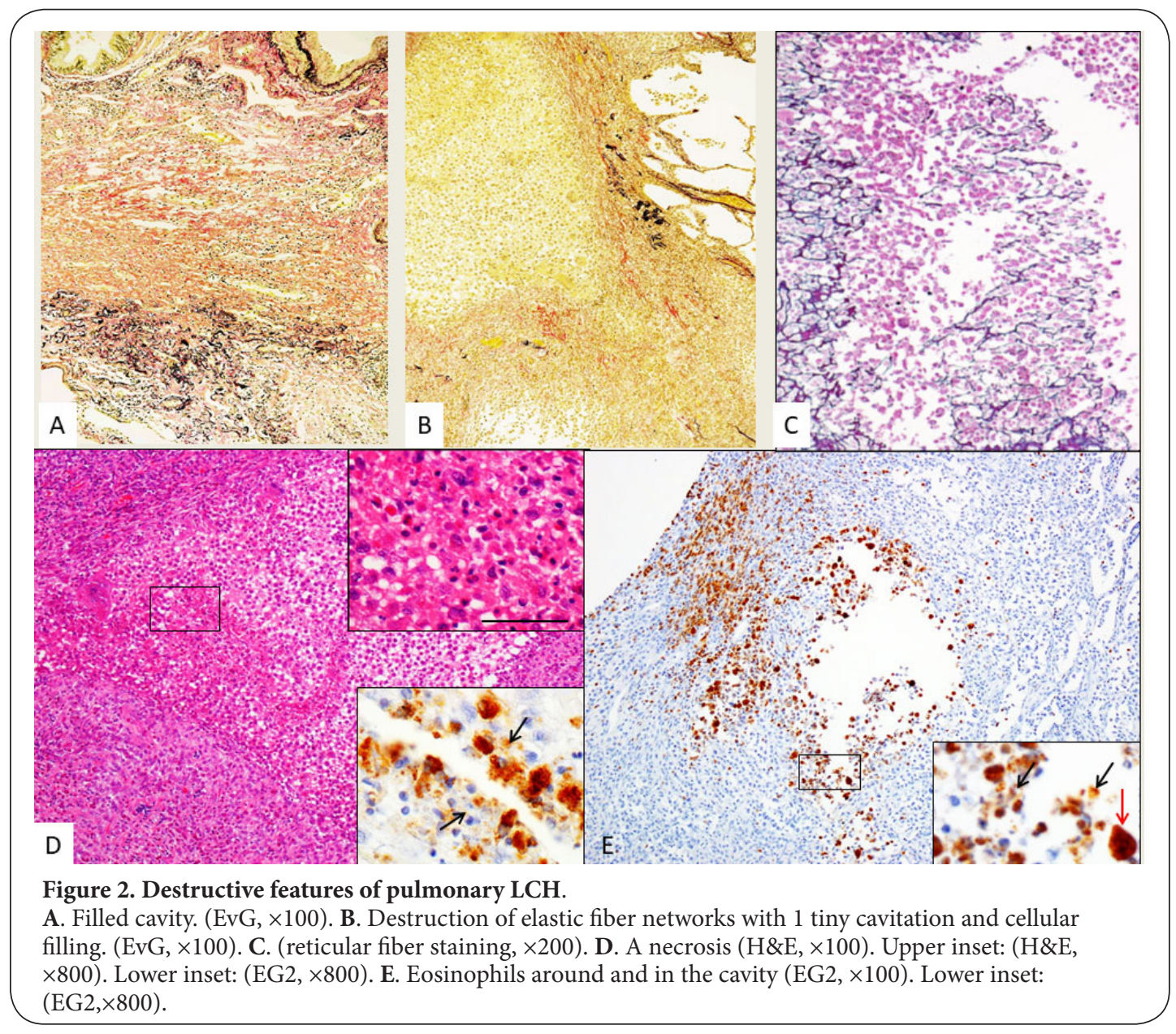


Kawabata et al., Journal of Histology \& Histopathology 2021, http://www.hoajonline.com/journals/pdf/2055-091X-8-1.pdf

Table 2. Density of inflammatory cells of the earliest lesion in the 33 pulmonary LCH cases (cellular [ $n=24]$, cellular and fibrous stage $[\mathbf{n}=9])$.

\begin{tabular}{|c|c|c|c|c|}
\hline & $\mathbf{N}$ & Positive & Density & Association \\
\hline Langerhans cells & 33 & -- & $2.6 \pm 0.6$ & -- \\
\hline Eosinophils & 33 & -- & $\begin{array}{l}2.1 \pm 0.9 \\
\text { NS }\end{array}$ & $\begin{array}{l}\mathrm{r}^{2}=0.2187 \\
P=0.0070\end{array}$ \\
\hline $\begin{array}{l}\text { Degranulation of } \\
\text { eosinophils }\end{array}$ & 33 & $55 \%$ & $0.9 \pm 0.9$ & $\begin{array}{l}\mathrm{r}^{2}=0.1614 \\
P=0.0227\end{array}$ \\
\hline Neutrophils & 33 & -- & $\begin{array}{l}0.7 \pm 0.8 \\
P<0.0001\end{array}$ & $\begin{array}{l}\mathrm{r}^{2}=0.1512 \\
P=0.0278\end{array}$ \\
\hline $\begin{array}{l}\text { Degranulation of } \\
\text { neutrophils }\end{array}$ & 33 & $18 \%$ & $0.3 \pm 0.5$ & NS \\
\hline CD4+ T cells & 28 & -- & $1.2 \pm 0.6$ & NS \\
\hline CD8+ T cells & 25 & -- & $1.3 \pm 0.7$ & NS \\
\hline
\end{tabular}

Association: association with Langerhans cells;

LCH: Langerhans cell histiocytosis;

$\mathrm{N}$ : examined number; NS: Not significant.

Table 3. Patient sex and age and pathological features of slides and degree of inflammatory cells of the earliest lesion in the 17 non-pulmonary Langerhans cell histiocytosis cases.

\begin{tabular}{lll}
\hline & $\begin{array}{l}\text { Number } \\
(\%)\end{array}$ & $\begin{array}{l}\text { Mean } \pm \text { SD } \\
\text { and significance }\end{array}$ \\
\hline Sex (male/female) & $10 / 7$ & -- \\
Age & -- & $20 \pm 20(1 \mathrm{M}-58 \mathrm{Y})$ \\
Necrosis of lesion & $8(47)$ & $0.5 \pm 1.0$ \\
Cavity formation & $5(30)$ & $1.8 \pm 0.1^{\star}$ \\
Shedding of inflammatory cells & $5(30)$ & -- \\
Destruction of reticuline fibers & $15(88)$ & -- \\
Representative lesion of the earliest cellular stage \\
Langerhans cells & -- & $3 \pm 0$ \\
Eosinophils & -- & $2.2 \pm 0.9, \mathrm{NS}$ \\
Degranulation of eosinophils (n=16) & $9(56)$ & $0.8 \pm 0.8$ \\
Neutrophils & -- & $1.1 \pm 0.9, P<0.001$ \\
Degranulation of neutrophils $(\mathrm{n}=14)$ & $3(21)$ & $0.2 \pm 0.4$ \\
\hline
\end{tabular}

M: month; Y: years; NS: not significant; SD: standard deviation.

${ }^{*}$ Among 5 cavities.

cell structure was preserved in 6 cases. Nuclear staining was either ghost-like or showed no staining (Figure 3A, inset). A few nuclear fragmentations were observed in 3 cases, and a few Charcot-Leyden crystals were noted in 2 cases (Figure 3D, inset arrow).

Infiltration of eosinophils and neutrophils into necrosis varied from area to area, and in 3 cases, both eosinophils and neutrophils (Figure 3D and 3E) had predominantly infiltrated into the necrotic area. The densities of the eosinophils and neutrophils were counted in the most infiltrated area and were 2.9 and 2.8 , respectively, with no statistical difference. Most of eosinophils in the necrotic areas were either dead or degenerated eosinophils (Figure 3D), but the neutrophils were all alive with a clear nucleus (Figure 3F). The densities of eosinophils and neutrophils with degranulation were 1.9 and 2.0, respectively (Figure 3D and 3F, black arrow), and were
Table 4. Characteristics of the necrosis in 8 non-pulmonary Langerhans cell histiocytosis cases.

\begin{tabular}{|c|c|c|}
\hline & Value & $P$-value \\
\hline Size $($ mean $\pm S D)$ & Grade $2.3 \pm 0.9$ & -- \\
\hline Numbers of necroses & $\begin{array}{l}4 \text { with multiple, } 1 \text { with } \\
\text { two, } 3 \text { with one necrosis }\end{array}$ & -- \\
\hline Character & 8 , coagulation necrosis & -- \\
\hline Necrotic cell structure & $\begin{array}{l}6 \text { preserved, } 2 \text { not pre- } \\
\text { served }\end{array}$ & -- \\
\hline $\begin{array}{l}\text { Nuclear staining and shape } \\
\text { of necrotic cells }\end{array}$ & $\begin{array}{l}6 \text { ghost-like with pre- } \\
\text { served shape, } 6 \text { with no } \\
\text { staining, } 3 \text { fragmented }\end{array}$ & -- \\
\hline Charcot-Leyden crystals & $\begin{array}{l}2 \text { (a few among grade } 3 \\
\text { necrosis) }\end{array}$ & -- \\
\hline \multicolumn{3}{|c|}{ Density of cellular infiltration } \\
\hline Eosinophils (mean \pm SD) & $2.9 \pm 0.6$ & $\mathrm{NS}^{*}$ \\
\hline $\begin{array}{l}\text { Degranulation of } \\
\text { eosinophils }(\text { mean } \pm S D)\end{array}$ & $1.9 \pm 0.4$ & $0.0030^{*}$ \\
\hline $\begin{array}{l}\text { Neutrophils (6) } \\
(\text { mean } \pm \text { SD) }\end{array}$ & $2.8 \pm 0.4, \mathrm{NS} \dagger$ & $0.0007^{\star}$ \\
\hline $\begin{array}{l}\text { Degranulation of neutro- } \\
\text { phils }(4)(\text { mean } \pm \text { SD) }\end{array}$ & $2.0 \pm 0.0$ & $0.0008^{*}$ \\
\hline
\end{tabular}

ND: not determined; NS: not significant; SD: standard deviation. ${ }^{\star}$ Density of cellular infiltration into the necrosis and degranulation and statistical comparison between the 17 lesions in Table 3 and the 8 necrotic lesions in Table 4.

$\dagger$ NS compared with eosinophils

statistically significantly denser than that in the 17 non-necrotic lesions. In one slide that contained multiple necroses, one area showed no eosinophils or neutrophils.

\section{Discussion}

In this study, we confirmed that a) pulmonary LCH showed a destructive process, including cyst/cavity formation and the destruction of arteries and of elastic and reticuline fiber networks; b) non-pulmonary LCH showed necrosis and a destructive process including cavity formation and reticuline fiber network destruction; c) dead eosinophils with degranulation were present to a significant degree in non-fibrotic, necrotic areas especially in non-pulmonary $\mathrm{LCH}$; and d) an early feature of the lesion was its composition of Langerhans cells and eosinophils. Focusing on necrosis and cavity formation, we found the frequency and degree of necrosis to be clearly different between lung and other organs and tried to develop a unified explanation for this difference.

$\mathrm{LCH}$ of bone is characterized by the destruction of bony trabeculae, infiltration of eosinophils, and frequently focal but occasionally extensive coagulation necrosis [14-17]. Degranulation of eosinophils (with the release of three cationic proteins) and subsequent uptake of the proteins in macrophages was reported but no mention was made of tissue necrosis [16]. LCH of lymph nodes also shows various degrees and frequencies of necrosis $[18,19]$. The presence of Charcot-Leyden crystals was noted in coagulation necrosis in 3 of 18 cases [18]. Overall, 


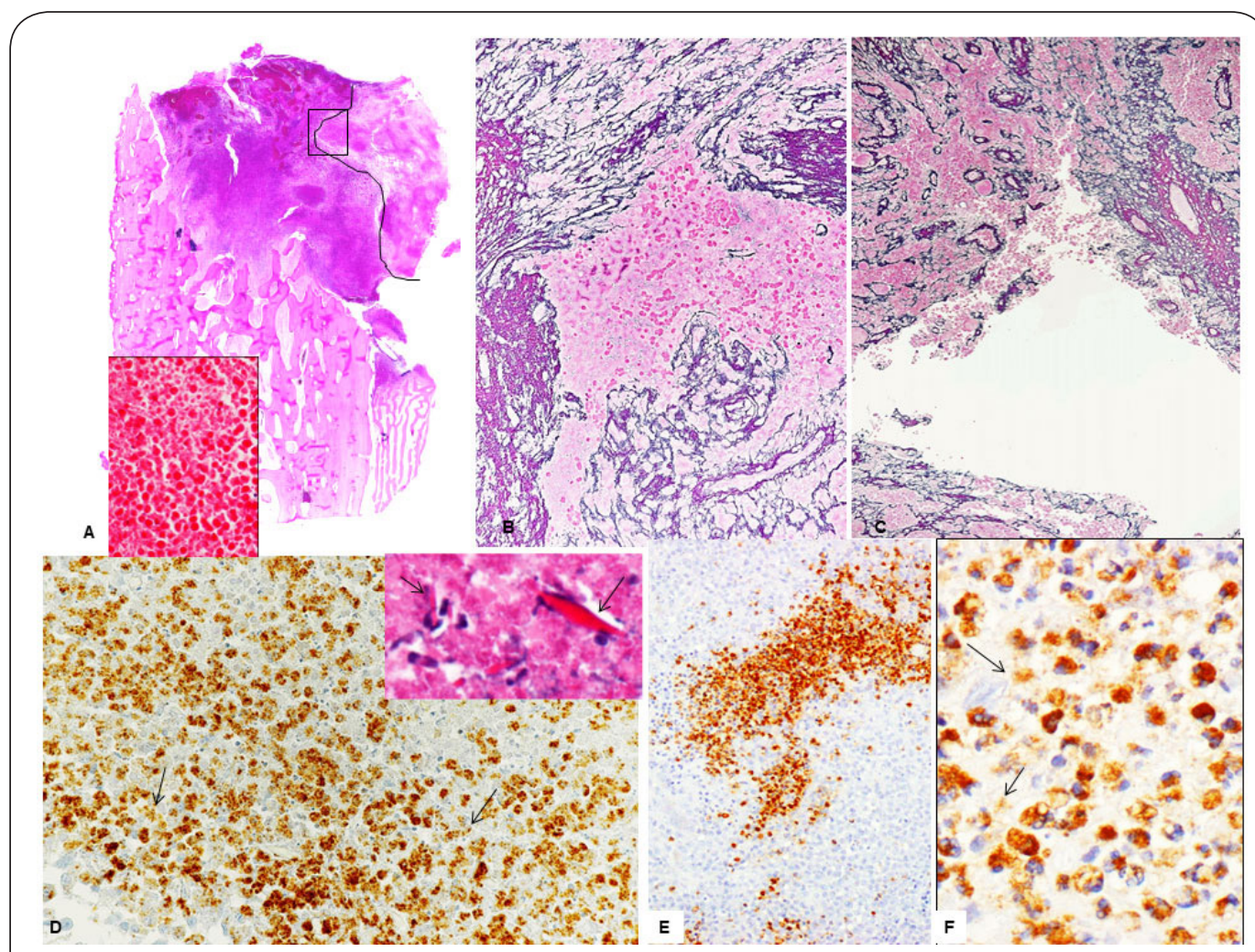

Figure 3. Necrosis, tissue destruction, and degranulation from granulocytes.

A. LCH of bone showing coagulation necrosis in the lined area (H\&E, panoramic view). Inset: (H\&E, $\times 800$ ). B. A necrotic area (reticular fiber staining, $\times 200$ ). C. (reticular fiber staining, $\times 100)$. D.Infiltration of necrotic eosinophils $(\mathrm{EG} 2, \times 600)$. Inset: $(\mathrm{H} \& \mathrm{E}, \times 800)$. E. Neutrophils in the necrotic area of a lymph node (anti-hNE antibody, $\times 150)$. F. Neutrophils in a portion of $\mathrm{E}($ anti-hNE antibody, $\times 800)$.

$\mathrm{LCH}$ of bone and lymph nodes showed a high frequency of coagulation necrosis and eosinophilic abscess [14-19]. We speculated that a) the earliest cellular lesion begins with the proliferation of Langerhans cells and infiltration of eosinophils, and b) by an unknown stimulus, eosinophilic degranulation in the cellular stage without fibrosis causes tissue necrosis, based on the presence of degranulated, dead eosinophils and some Charcot-Leyden crystals remaining in necrotic area with reticuline network destruction as a preceding phenomenon. Massive infiltration of neutrophils with degranulation might be a secondary phenomenon following necrosis as most of the cellular staged lesions contained limited numbers of neutrophils. Necrosis and subsequent destruction of lung structure and cavitation due to degranulation of eosinophils in parasitic pulmonary infections were reported because of the presence of dead eosinophils with degranulation and the escape of worms from the disrupted artery in necrosis $[\mathbf{2 0 , 2 1 ]}$. Meanwhile, it was reported that the number of neutrophils equaled or exceeded the number of eosinophils in $21 \%$ of cases [14]. In the present study, detection of neutrophils was based on enzyme activity (elastase), and degranulation of neutrophils was limited to live cells. When neutrophils die, no enzyme activity can be detected by this method. One area of necrosis showed no dead eosinophils, so it is possible that neutrophilic degranulation caused coagulation necrosis followed by death of the neutrophils and the complete disappearance of enzyme activity. However, we could not confirm the role of neutrophils in necrosis at this time.

How can the high frequency of cyst/cavity formation of pulmonary LCH [22-28] and various forms of tissue destruction including vascular destruction be explained? There are different reports concerning the nature and the mechanism of cyst/cavity formation. As for its nature, it is separated between cavities [23-27] and cysts $[\mathbf{2 2}, \mathbf{2 8}]$, and as for the mechanism, both necrosis $[\mathbf{2 3}, \mathbf{2 6}]$ and bronchiolar epithelial damage progressing to dilatation (cysts) $[\mathbf{2 2 , 2 8 ]}$ are reported. A small percentage of necrosis is reported, but progression of necrosis to cavity formation is not mentioned $[23,26]$. One of the present authors (YK) observed coagulation necrosis of 2 $\mathrm{mm}$ in size in the center of the lesion of an unreported case (personal experience). Although the frequency and degree of necrosis are mild, we think necrosis can explain subsequent phenomena including cavitation and filling of tissue defects because pulmonary LCH and non-pulmonary $\mathrm{LCH}$ are the same disease, and cavitation always follows necrosis. We speculated that necrosis would take place at the cellular stage 
of LCH like non-pulmonary LCH as a) necrotic area showed destruction of the reticuline network without fibrosis, and b) almost all cell shedding with/without reticuline fiber network destruction into cavities was observed at this stage. The initial size of the necrosis might not be extensive, but soon, the size of the cavity enlarges due to the mechanism of an early-staged tension cavity seen in pulmonary tuberculous [29] or to traction from surrounding normal lung such as laceration of the lung seen in vascular Ehlers-Danlos syndrome [13] or in trauma. Cellular and degenerated tissue shedding into this cavity might result in continuous enlargement of the cavity. The necrotic material might soon be discharged from the cavity, and this might be the main reason why the histological specimens did not contain necrotic materials in the cavity in contrast with non-pulmonary LCH. An increase of Langerhans cells from bronchoalveolar lavage fluid [30-32] might also reflect discharge of Langerhans cells from the cavity. When the cavity is filled with granulation tissue as for repair, it may result in a nodule as seen in Figure 2A. Pulmonary LCH is also thought to be incited by cigarette smoking in certain predisposed individuals $[8,33]$.

Patients with involvement of single-system LCH in one organ have an excellent prognosis [34]. When patients show a protracted course, therapy to suppress eosinophilic activity, such as stopping smoking, might be a one choice in singlesystem $\mathrm{LCH}$, including non-pulmonary LCH, as smoking activates eosinophils as in acute eosinophilic pneumonia [35].

Limitations of this study include its retrospective design, and thus we could not stain cytokines to induce and activate eosinophils and neutrophils in LCH. We also could not examine the role of Langerhans cells, T helper cells, and macrophages in tissue damage and necrosis.

\section{Conclusion}

The present findings suggest an intimate relationship between the preceding degranulation of dead eosinophils in necrosis and various kinds of tissue destruction both in non-pulmonary and pulmonary $\mathrm{LCH}$. Further investigation to prevent necrosis is the next important step in the control of single-system LCH.

\section{List of Abbreviations}

EvG: Elastica van Gieson

H\&E: Hematoxylin and eosin

HPF: High-power field

LCH: Langerhans cell histiocytosis

SD: Standard deviation

\section{Competing interests}

The authors declare that they have no competing interests.

\section{Acknowledgements}

We are very grateful to the late Dr. Hiroshi Kishimoto

(Department of Diagnostic Pathology, Saitama Children's

Medical Center), Hiroshi Ishii (Department of Respiratory

Medicine, Oita University Hospital,now at Fukuoka University),
Yuuji Ishimatsu (Department of Respiratory Medicine, Nagasaki University Hospital), Keiichi Iwabuchi (Department of Diagnostic Pathology, Kitazato University Hospital), Toshimasa Uekusa (Department of Diagnostic Pathology, Juntendo University Hospital, now at Kanto Rousai Hospital), Yuuji Ohtsuki (Department of Diagnostic Pathology, Matsuyama Municipal Hospital), Toshiaki Kawai (Department of Diagnostic Pathology, Jieitai Central Hospital), Takehumi Saito (Department of Respiratory Medicine, National Hospital Organization IbarakiHigashi Hospital), Kazumi Sakata (Department of Diagnostic Pathology, Kawaguchi Municipal Medical Center), Tatsuo Sawada (Department of Diagnostic Pathology, Tokyo Women's Medical University Hospital), Masahiko Sugitani, (Departmentof Pathology, Nihon University School of Medicine), Kunihiko Seki (Department of Diagnostic Pathology, JR Tokyo General Hospital), Makio Mukai (Department of Diagnostic Pathology, Keio University Hospital), Tamiko Takemura (Department of Diagnostic Pathology, Japanese Red Cross Medical Center), Akira Hebisawa (Department of Diagnostic Pathology, National Hospital Organization Tokyo Hospital), and Sakae Homma (Department of Respiratory Medicine, Toho University Graduate School of Medicine) for presenting cases and discussion.

Authors' contributions

\begin{tabular}{|l|c|c|c|c|c|c|c|c|}
\hline Authors' contributions & YK & NT & MAT & TO & MK & YF & KK & YS \\
\hline $\begin{array}{l}\text { Research concept and } \\
\text { design }\end{array}$ & $\checkmark$ & $\checkmark$ & $\checkmark$ & $\checkmark$ & $\checkmark$ & $\checkmark$ & $\checkmark$ & $\checkmark$ \\
\hline $\begin{array}{l}\text { Collection and/or } \\
\text { assembly of data }\end{array}$ & $\checkmark$ & $\checkmark$ & $\checkmark$ & $\checkmark$ & $\checkmark$ & $\checkmark$ & $\checkmark$ & $\checkmark$ \\
\hline $\begin{array}{l}\text { Data analysis and } \\
\text { interpretation }\end{array}$ & $\checkmark$ & $\checkmark$ & $\checkmark$ & $\checkmark$ & $\checkmark$ & $\checkmark$ & $\checkmark$ & $\checkmark$ \\
\hline Writing the article & $\checkmark$ & -- & -- & -- & -- & -- & -- & -- \\
\hline $\begin{array}{l}\text { Critical revision of the } \\
\text { article }\end{array}$ & -- & $\checkmark$ & -- & -- & -- & -- & -- & $\checkmark$ \\
\hline Final approval of article & $\checkmark$ & $\checkmark$ & $\checkmark$ & $\checkmark$ & $\checkmark$ & $\checkmark$ & $\checkmark$ & $\checkmark$ \\
\hline Statistical analysis & -- & -- & -- & -- & -- & -- & $\checkmark$ & -- \\
\hline
\end{tabular}

Publication history

Editor: Khin Thway, The Royal Marsden Hospital, UK. Received: 02-Jan-2021 Final Revised: 02-Mar-2021

Accepted: 05-Mar-2021 Published: 18-Mar-2021

\section{References}

1. Lichtenstein L: Histiocytosis $\mathbf{X}$; integration of eosinophilic granuloma of bone, Letterer-Siwe disease, and Schüller-Christian disease as related manifestations of a single nosologic entity. AMA Arch Pathol.1953; 56:84-102.PubMed

2. Histiocytosis syndromes in children. Writing Group of the Histiocyte Society. Lancet.1987;1(8526):208-9.PubMed

3. Badalian-Very G,VergilioJA, Degar BA,MacConaill LE, Brandner B,Calicchio ML, Kuo FC, Ligon AH,Stevenson KE,Kehoe SM, Garraway LA,HahnWC,Meyerson M,Fleming MD and Rollins BJ:Recurrent BRAF mutations in Langerhans cell histiocytosis. Blood. 2010;116:1919-23. PubMed

4. Berres ML, Lim KP, Peters T, Price J, Takizawa H, Salmon H, Idoyaga J, Ruzo A, Lupo PJ, Hicks MJ, Shih A, Simko SJ, Abhyankar H, Chakraborty R, Leboeuf M, Beltrão M, Lira SA, Heym KM, Bigley V, Collin M, Manz MG, McClain K, Merad M and Allen CE:BRAF-V600E expression in precursor versus differentiated dendritic cells defines clinically distinct $\mathrm{LCH}$ risk groups. J Exp Med.2014; 211:669-83.PubMed

5. Emile JF, Abla O,Fraitag $S$, Horne A, Haroche J, Donadieu J, RequenaCaballero L, Jordan MB, Abdel-Wahab O, Allen CE, Charlotte F, Diamond 
EL, Egeler RM, Fischer A, Herrera JG, Henter JI, Janku F, Merad M, Picarsic J, Rodriguez-Galindo C, Rollins BJ, Tazi A, Vassallo R, Weiss LM and Histiocyte Society:Revised classification of histiocytoses and neoplasms of the macrophage-dendritic cell lineages. Blood.2016; 127:2672-81. PubMed

6. Lichtenstein $\mathrm{L}$ and Jeffe $\mathrm{HL}$ :Eosinophilic granuloma of bone: with report of a case.Am J Pathol.1940; 16:595-604.PubMed

7. Brauner MW, Grenier P, Tijani K, Battesti JP and Valeyre D:Pulmonary Langerhans cell histiocytosis: evolution of lesions on CT scans. Radiology, 1997; 204:497-502.PubMed

8. Tazi A, Soler P and Hance AJ:Adult pulmonary Langerhans' cell histiocytosis. Thorax. 2000;55:405-16.PubMed

9. Egeler RM, Favara BE, van Meurs M, Laman JD and Claassen $\mathrm{E}$ :Differential in situ cytokine profiles of Langerhans-like cells and $T$ cells in Langerhans cell histiocytosis:abundant expression of cytokines relevant to disease and treatment. Blood. 1999; 94:4195-201.PubMed

10. Rizzo FM, Cives $M$, Simone $V$ and Silvestris $F$ :New insights into the molecular pathogenesis of Langerhans cell histiocytosis. Oncologist. 2014;19:151-63. PubMed

11. Morimoto $A$, Oh $Y$, Shioda $Y$, Kudo $K$ and Imamura $T$ :Recent advances in Langerhans cell histiocytosis. Pediatr Int. 2014;56:451-61.PubMed

12. Iwasaki T:Cure of Cavity. In Iwasaki T (ed), Pathology of Tuberculosis. 1951,122-6. In Japanese.

13. Kawabata Y, Watanabe A, Yamaguchi S, Aoshima M, Shiraki A, Hatamochi A,Kawamura T, Uchiyama T,Watanabe A and Fukuda Y:Pleuropulmonary pathology of vascular Ehlers-Danlos syndrome: laceration, haematoma, and fibrous nodules. Histopathology. 2010;56:944-50.PubMed

14. Kilpatrick SE, Wenger DE, Gilchrist GS, Shives TC, Wollan PC and Unni KK:Langerhans' cell histiocytosis (histiocytosis $X$ ) of bone. A clinicopathologic analysis of $\mathbf{2 6 3}$ pediatric and adult cases. Cancer. 1995;76:2471-84.PubMed

15. Wang J, Wu X and Xi ZJ:Langerhans cell histiocytosis of bone in children: a clinicopathologic study of 108 cases. World J Pediatr. 2010;6:255-9. PubMed

16. Janin A, Torpier G, Capron M, Courtin P and Gosselin B:Immunopathological study of eosinophils in eosinophilic granuloma of bone: evidence for release of three cationic proteins and subsequent uptake in macrophages. Virchows Arch A Pathol Anat Histopathol. 1992;421:255-61. PubMed

17. Xu X, Liu WP, Yang QP, Wang WY, Liao DY, Zhao S,Bi CF, Lin L and Min M:Langerhans cell histiocytosis: a clinicopathologic and immunohistochemical analysis of 258 cases. Zhonghua Bing Li Xue Za Zhi. 2012;41:91-6. (In Chinese with English abstract).PubMed

18. Motoi M, Helbron D, Kaiserling E and Lennert K:Eosinophilic granuloma of lymph nodes--a variant of histiocytosis X. Histopathology. 1980;4:585-606.PubMed

19. Favara BE and Steele A:Langerhans cell histiocytosis of lymph nodes: a morphological assessment of $\mathbf{4 3}$ biopsies. Pediatr Pathol Lab Med. 1997;17:769-87.PubMed

20. Araya J, Kawabata Y, Tomichi N, Kaneko K, Hayashi K, Iwabuchi K,Terasaki $\mathrm{Y}$, Kawashima Tand Watanabe M: Allergic inflammatory reaction is involved in necrosis of human pulmonary dirofilariasis. Histopathology. 2007;51:484-90.PubMed

21. Ota K, Matsuyama M, Kokuho N, Masuko H, Hayashi $\mathrm{H}$, lizuka T,Hayashibara K, Saito T, Kawabata Y and Tomichi N:A case of paragonimiasis miyazakii suspected after pathologic examination and subsequently confirmed. Nihon Kokyuki Gakkai Zasshi. 2009;47:232-6. (In Japanese with English abstract).PubMed

22. Basset F, Corrin B, Spencer H, Lacronique J, Roth C, Soler P, Battesti JP, Georges R and Chrétien J:Pulmonary histiocytosis X. Am Rev Respir Dis. 1978;118:811-20. PubMed

23. Friedman PJ, Liebow AA and Sokoloff J:Eosinophilic granuloma of lung. Clinical aspects of primary histiocytosis in the adult. Medicine (Baltimore). 1981;60:385-96.PubMed

24. Colby TV and Lombard C:Histiocytosis $\mathbf{X}$ in the lung. Hum Pathol1983;14:847-56.PubMed
25. Fukuda Y, Basset F, Soler P, Ferrans VJ, Masugi Y and Crystal $R G$ :Intraluminal fibrosis and elastic fiber degradation lead to lung remodeling in pulmonary Langerhans cell granulomatosis (histiocytosis X). Am J Pathol. 1990;137:415-24.PubMed

26. Travis WD, Borok Z, Roum JH, Zhang J, Feuerstein I, Ferrans VJ and Crystal RG: Pulmonary Langerhans cell granulomatosis (histiocytosis X). A clinicopathologic study of 48 cases. Am J Surg Pathol. 1993;17:971-86. PubMed

27. Kawabata Y, Kaneko K, Nagayama G and Matsubara O:Pathology of pulmonary eosinophilic granuloma and its pathogenesis. Kokyu. 1996;15:1317-23. In Japanese.

28. Kambouchner M, Basset F, Marchal J, Uhl JF, Hance AJ and Soler P:Threedimensional characterization of pathologic lesions in pulmonary langerhans cell histiocytosis. Am J Respir Crit Care Med.2002;166:148390.PubMed

29. Pearson SV:The pathogenesis of pulmonary cavities. $\mathrm{Br}$ Med J. 1930;1:380-1.PubMed

30. Chollet S, Soler P, Dournovo P,Richard MS, Ferrans VJ and Basset $\mathrm{F}$ :Diagnosis of pulmonary histiocytosis $\mathrm{X}$ by immunodetection of Langerhans cells in bronchoalveolar lavage fluid. $\mathrm{Am} \mathrm{J}$ Pathol.1984;115:225-32.PubMed

31. Auerswald U, Barth J and Magnussen $\mathrm{H}$ : Value of CD-1-positive cells in bronchoalveolar lavage fluid for the diagnosis of pulmonary histiocytosis X. Lung. 1991;169:305-9.PubMed

32. Baqir $M$, Vassallo R, Maldonado F, Yi ES and Ryu JH:Utility of bronchoscopy in pulmonary Langerhanscell histiocytosis. J Bronchology Intervent Pulmonol. 2013;20:309-12.PubMed

33. SuriHS, Yi ES, Nowakowski GS and Vassallo R:Pulmonary langerhans cell histiocytosis. Orphanet J Rare Dis. 2012,7:16.PubMed

34. Hutter C and Minkov M: Insights into the pathogenesis of Langerhans cell histiocytosis: the development of targeted therapies. Immunotargets Ther. 2016;5:81-91. PubMed

35. Allen JN, Pacht ER, Gadek JE and Davis WB:Acute eosinophilic pneumonia as a reversible cause of noninfectious respiratory failure. $N$ Engl J Med.1989;321:569-74.PubMed

\section{Citation:}

Kawabata Y, Tomichi N, Tanino MA, Ogura T, Kawamoto M, Fukushima Y, Kurashima K and Shimizu $Y$. The role of eosinophils in necrosis mainly in single-system Langerhans cell histiocytosis. J Histol Histopathol. 2021; 8:1.

http://dx.doi.org/10.7243/2055-091X-8-1 